\title{
Pelagic and epiphytic summer distributions of Prorocentrum lima and $P$. mexicanum at two mussel farms in the Gulf of St. Lawrence, Canada
}

\author{
Maurice Levasseur ${ }^{1, *}$, Jean-Yves Couture ${ }^{1}$, Andréa M. Weise ${ }^{1}$, Sonia Michaud ${ }^{1}$, \\ Malte Elbrächter ${ }^{2}$, Gilbert Sauvé ${ }^{3}$, Esther Bonneau ${ }^{1}$ \\ ${ }^{1}$ Institut Maurice-Lamontagne, Ministère des Pêches et des Océans, CP 1000, Mont-Joli, Québec G5H 3Z4, Canada \\ ${ }^{2}$ Deutsches Zentrum für Marine Biodiversität, FI Senckenberg, Wattenmeerstation Sylt, Alfred Wegener Institut für Polar- \\ und Meeresforschung, Hafenstr. 43, 25992 List/Sylt, Germany \\ ${ }^{3}$ Agence Canadienne d'Inspection des Aliments, 901 Cap Diamant, Québec, Québec G1K 4K1, Canada
}

\begin{abstract}
The variations in abundance of Prorocentrum lima (Ehrenberg) Stein, an epiphythic species implicated in diarrhetic shellfish poisoning (DSP), were studied during the summer of 1999 in the Magdalen Islands, an archipelago located in the southern Gulf of St. Lawrence, eastern Canada. This investigation was initiated as a result of an incident in 1998, when 20 people became ill and exhibited DSP-like symptoms following the consumption of blue mussels collected from one of the Magdalen Islands lagoons. P. lima was regularly found as an epiphyte on the epibionts growing on the mussel socks at the 2 aquaculture sites investigated between June and October 1999. P. lima abundance on the epibionts varied from 100 to 9600 cells g ${ }^{-1}$ dry wt epibiont, with maximum abundances observed in July and August. P. lima was found in low abundance in the water column as well as in the digestive glands of the mussels. There was no correlation between cell abundances in the digestive glands, the water column and the cells attached to the epibionts. At the same sites, P. mexicanum Tafall was identified for the first time in eastern Canada. P. mexicanum abundances were low throughout the summer and began to increase both in the water column and in mussel digestive glands by early September. A significant correlation was found between the P. mexicanum abundances in the water column and in the mussel digestive glands at both sampling sites. The identification of these 2 potentially toxic species in the St. Lawrence highlights the importance of Prorocentrum spp. as toxin producers in coastal waters, as well as the need for adequate monitoring of non-pelagic harmful algal bloom species (HABs).
\end{abstract}

KEY WORDS: Prorocentrum lima - Prorocentrum mexicanum - Diarrhetic shellfish poisoning • Epiphytes $\cdot$ Mussel culture $\cdot$ Toxic dinoflagellate $\cdot$ Biofouling community

\section{INTRODUCTION}

Toxic phytoplankton species implicated in diarrhetic shellfish poisoning (DSP), particularly Dinophysis spp. and certain benthic/epiphytic Prorocentrum spp., commonly occur in Canadian waters (Cembella

${ }^{*}$ Present address: Département de biologie, Québec-Océan, Université Laval, Ste-Foy, Québec G1K 7P4, Canada.

Email: maurice.levasseur@bio.ulaval.ca et al. 1992). In several European countries, a link has been shown between Dinophysis spp. and DSP (as reviewed by Sournia et al. 1991). However, in eastern Canadian waters, Dinophysis blooms appear to be non-toxic or may be only facultatively toxic under certain environmental conditions since blooms of more than 50000 cells $~^{-1}$ have not resulted in substantial DSP toxin accumulation (Cembella et al. 1992). In North America, the only confirmed case of DSP occurred in August 1990 when 13 people became ill 
after consuming cultured blue mussels from Mahone Bay, Nova Scotia (Quilliam et al. 1993). The DSP toxins found in the mussels were not associated with the Dinophysis-rich samples collected following the incident. However, another dinoflagellate, Prorocentrum lima (Ehrenberg) Stein, isolated from the same area, was found to be a producer of okadaic acid (OA) and dinophysistoxin-1 (DTX-1) in unialgal cultures (Marr et al. 1992). A study carried out later by Lawrence et al. (1998) suggested that P. lima could have been responsible for the accumulation of DSP toxins at this site. Similarly, on the east coast of Maine, USA, following several unexplained incidents of shellfish-related gastroenteritis, Morton et al. (1999) showed that DSP toxicity was found only in phytoplankton or mussel digestive gland samples containing P. lima. P. lima occurs worldwide in coastal areas, in temperate and tropical oceans and mostly in benthic and epiphytic habitats (Faust et al. 1999). In eastern Canada, this dinoflagellate has already been found in substantial concentrations in the water column and attached to vegetation at aquaculture sites in the Miramichi estuary, New Brunswick (Bates 1997), and near Indian Point, Nova Scotia (Lawrence et al. 2000).

In 1998, 20 people exhibited DSP-like symptoms following the consumption of cultured blue mussels from the Magdalen Islands in the Gulf of St.

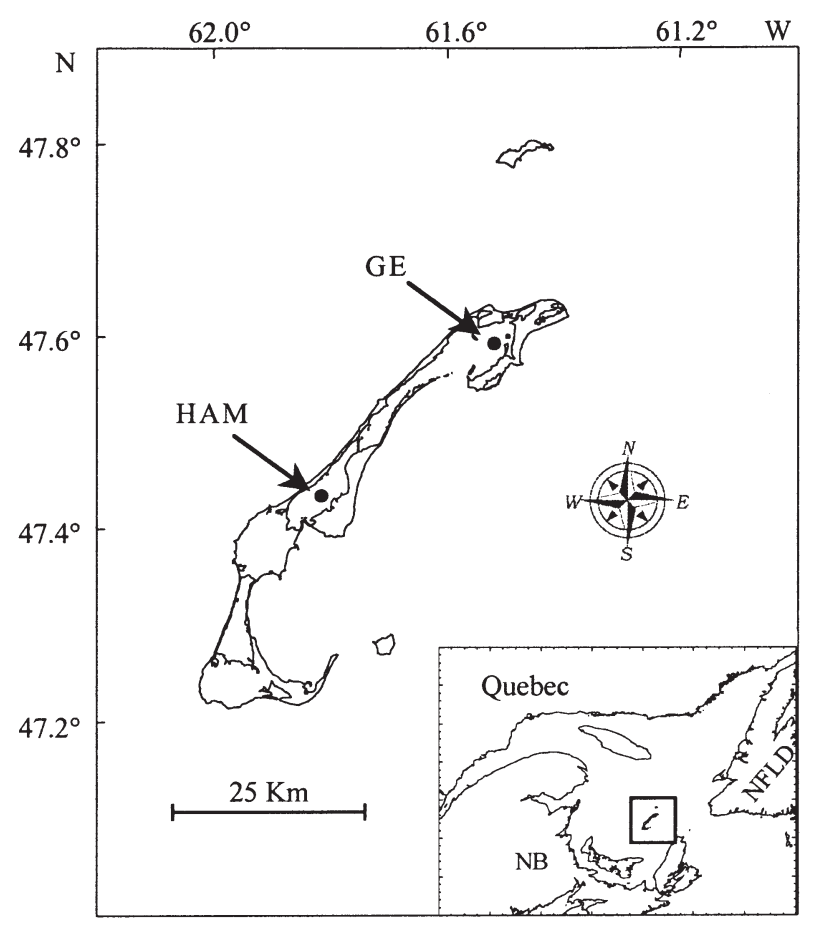

Fig. 1. Sampling sites of Havre-aux-Maisons (HAM) and Grande-Entrée (GE) at the Magdalen Islands, eastern Canada. NB: New Brunswick; NFLD: Newfoundland
Lawrence, Canada. The analyses revealed that the mussels contained DTX-1 (no OA), but in too a low concentration to explain the symptoms $\left(0.1 \mathrm{\mu g} \mathrm{g}^{-1}\right.$ digestive gland; regulatory limit $\left.1.0 \mu \mathrm{g} \mathrm{g}^{-1}\right)$. This prompted us to initiate a study to determine the source of DTX-1 in the Magdalen Islands, with a focus on Prorocentrum lima which has been previously detected in the lagoons. Our specific objectives were: (1) to determine the seasonal variations of $P$. lima concentrations on the epibionts fouling the mussel socks, in the water column and in mussel digestive glands; and (2) to measure the concentrations of OA and DTX-1 in mussel digestive glands. Our study also led to the discovery of $P$. mexicanum Tafall, another potentially toxic species (Tindall et al. 1984, 1989, Pearce \& Hallegraeff 2001).

\section{MATERIALS AND METHODS}

Study site. The Magdalen Islands are located in the southern Gulf of St. Lawrence (Fig. 1). The 7 islands of this archipelago are connected by sand bars which form 3 shallow lagoons of $7 \mathrm{~m}$ maximum depth. The sampling was conducted at 2 mussel farming sites located in the Havre-aux-Maisons (HAM) and GrandeEntrée (GE) lagoons (Fig. 1). A distance of ca. $30 \mathrm{~km}$ separates the 2 sampling sites, and water circulation between the 2 lagoons is limited to a narrow channel. The mussel species cultured at these sites are Mytilus edulis and Mytilus trossulus.

Field sampling. The mussel farming sites were sampled weekly between 06:00 and 09:00 h from June 30 to October 11, 1999. Sampling consisted of collecting epibionts (composed of hydrozoans and macroalgae intertwined around a mussel sock), mussels, phytoplankton and seawater. Epibionts and mussels were collected by a diver at the bottom of a sock ( $4.5 \mathrm{~m}$ depth at HAM and $6 \mathrm{~m}$ depth at GE). To keep the depth of the sampled mussels and associated epibionts constant, successive socks suspended on a common horizontal line were sampled from week to week. First, the diver collected the epibionts growing on the bottom of the sock with an 81 polyethylene bag. Thereafter, the last ca. $30 \mathrm{~cm}$ of the cleaned mussel sock was cut and put in a second 81 polyethylene bag. Phytoplankton was then collected from a small boat using a $2 \mathrm{~m}$ conical $\mathrm{Nytex}^{\circledR}$ net (20 $\mu \mathrm{m}$ mesh size) installed on a $0.5 \mathrm{~m}$ diameter metal ring, and ending with a 0.31 codend. A vertical tow was performed between $0-5 \mathrm{~m}$ at HAM and $0-6 \mathrm{~m}$ at GE. Phytoplankton samples were preserved with a Lugol's solution to a final concentration of $1 \%$ $(\mathrm{v} / \mathrm{v})$. Finally, a water sample from $4.5 \mathrm{~m}$ at HAM and $6 \mathrm{~m}$ at GE was collected with a 21 Niskin bottle 
to measure salinity, water temperature (with a mercury thermometer) and nutrient concentrations $\left(\mathrm{NO}_{2}, \mathrm{NO}_{3}\right.$ and $\left.\mathrm{PO}_{4}\right)$. Daily wind speed and direction were obtained from the meteorological station of the HAM airport.

Laboratory analyses. Salinity was measured with a SCT salinometer (YSI model 33). Samples for nutrient analysis were filtered using an Acrodisc $25 \mathrm{~mm}$ syringe filter with a $0.8 \mu \mathrm{m}$ Versapor membrane and the filtrates frozen in polypropylene cryovials at $-40^{\circ} \mathrm{C}$ for later analysis using a Technicon auto-analyzer $^{\circledR}$ (Parsons et al. 1984). Epiphytic microalgae were quantified using a modified version of the method of Yasumoto et al. (1979). The bags containing the epibionts were vigorously shaken for 2 min to dislodge the epiphytic microalgae from the epibionts. All material was poured through stacked 350, 150, 100 and $20 \mu \mathrm{m}$ sieves, and thoroughly rinsed with $0.7 \mu \mathrm{m}$ filtered seawater. The macroalgae and hydrozoans collected on the 350, 150 and $100 \mu \mathrm{m}$ sieves were identified and rinsed with distilled water to remove salts, freeze-dried and weighed. Microalgae, including Prorocentrum spp., were collected on the $20 \mu \mathrm{m}$ sieve. The cells were resuspended in a known volume of filtered seawater and a subsample was preserved with a Lugol's solution to a final concentration of $1 \%(\mathrm{v} / \mathrm{v})$. Epiphytic microalgae from the epibionts and phytoplankton from the vertical tows were enumerated in a $5 \mathrm{ml}$ Palmer-Maloney counting chamber with an inverted microscope at 250× magnification. The abundances of Prorocentrum cells are expressed respectively as cells $\mathrm{g}^{-1}$ dry wt epibiont and cells $\mathrm{m}^{-3}$. It is important to note that the Prorocentrum abundances measured in the water column were very low and only semi-quantitative, since the volume of filtered seawater was an approximation due to the possibility of water overflowing the net as it was raised through the water column.

On each sampling day, 50 to 60 mussels were dissected to extract the digestive glands. Half of the samples were frozen and sent to the Canadian Food Inspection Agency (CFIA) for DSP toxin analyses using the method of Van de Riet et al. (1995). The other half was used for the gut content analyses. The digestive glands were weighed and triturated into a $2 \mathrm{~mm}$ grid to release microalgal cells. The material was then poured onto successively stacked 100 and $20 \mu \mathrm{m}$ sieves, and thoroughly rinsed with $0.7 \mu \mathrm{m}$ filtered seawater. Material collected on the $20 \mu \mathrm{m}$ sieve was resuspended in $400 \mathrm{ml}$ filtered seawater. A $200 \mathrm{ml}$ subsample was preserved with a Lugol's solution to a final concentration of $1 \%$ (v/v). All Prorocentrum spp. cells were enumerated, as described earlier, and the abundance was reported in cells $\mathrm{g}^{-1}$ wet wt digestive gland.

\section{RESULTS}

\section{Havre-aux-Maisons (HAM)}

Physico-chemical parameters

Water salinity varied between 27.5 and $31.5 \%$ from the end of June to mid-October (Fig. 2a). Water temperature varied between 17 and $21.5^{\circ} \mathrm{C}$ from late June to mid-September and decreased to $10.5^{\circ} \mathrm{C}$ thereafter (Fig. 2b). Inorganic nutrient concentrations were low, with nitrogen $\left(\mathrm{NO}_{3}+\mathrm{NO}_{2}\right)$ and phosphate $\left(\mathrm{PO}_{4}\right)$ concentrations remaining below 0.35 and $0.65 \mu \mathrm{mol} \mathrm{l}^{-1}$ respectively (data not shown). Nutrient concentrations exhibited no particular temporal pattern.

\section{Abundance and nature of the epibionts}

The total biomass of the sampled epibionts ranged between 3 and $8 \mathrm{~g}$ dry wt between June 30 and September 15, increased sharply to $19 \mathrm{~g}$ dry epibiont wt on September 22, and remained above $15 \mathrm{~g}$ dry epibiont wt until the end of the sampling on October 11 (Fig. 2c). The sharp increase in biomass observed in September was principally due to the appearance of the rhodophyte Trailliella intricata which formed very dense clusters. The epibiontic assemblage was composed of hydrozoans and a succession of macroalgal species belonging to 3 divisions: Chlorophyta, Phaeophyta and Rhodophyta. From June 30 to August 11, the chlorophytes Ulva lactuca, Rhizoclonium spp. and Chaetomorpha spp. dominated the assemblage (Fig. 2c). During this period, Polysiphonia spp. were also present but in lower abundance. From August 11 to September 15, the phaeophytes Ectocarpus spp. gradually replaced the chlorophytes. From September 22, Ectocarpus spp. were replaced by the rhodophyte T. intricata. In October, T. intricata was responsible for ca. $50 \%$ of the total biomass, while the other half consisted of hydrozoans.

\section{Prorocentrum lima distribution}

Prorocentrum lima was found attached to the epibionts, free in the water column and in mussel digestive glands during the whole sampling period. The abundances of attached $P$. lima were low in late June, increased during July and reached a maximum of 9671 cells g ${ }^{-1}$ dry epibiont wt on August 4 (Fig. 2d). Thereafter, their abundances decreased and remained around 4000 cells g $^{-1}$ dry epibiont wt up to September 15 , and abruptly decreased again and remained under 1000 cells $\mathrm{g}^{-1}$ dry epibiont wt until the end of the sam- 

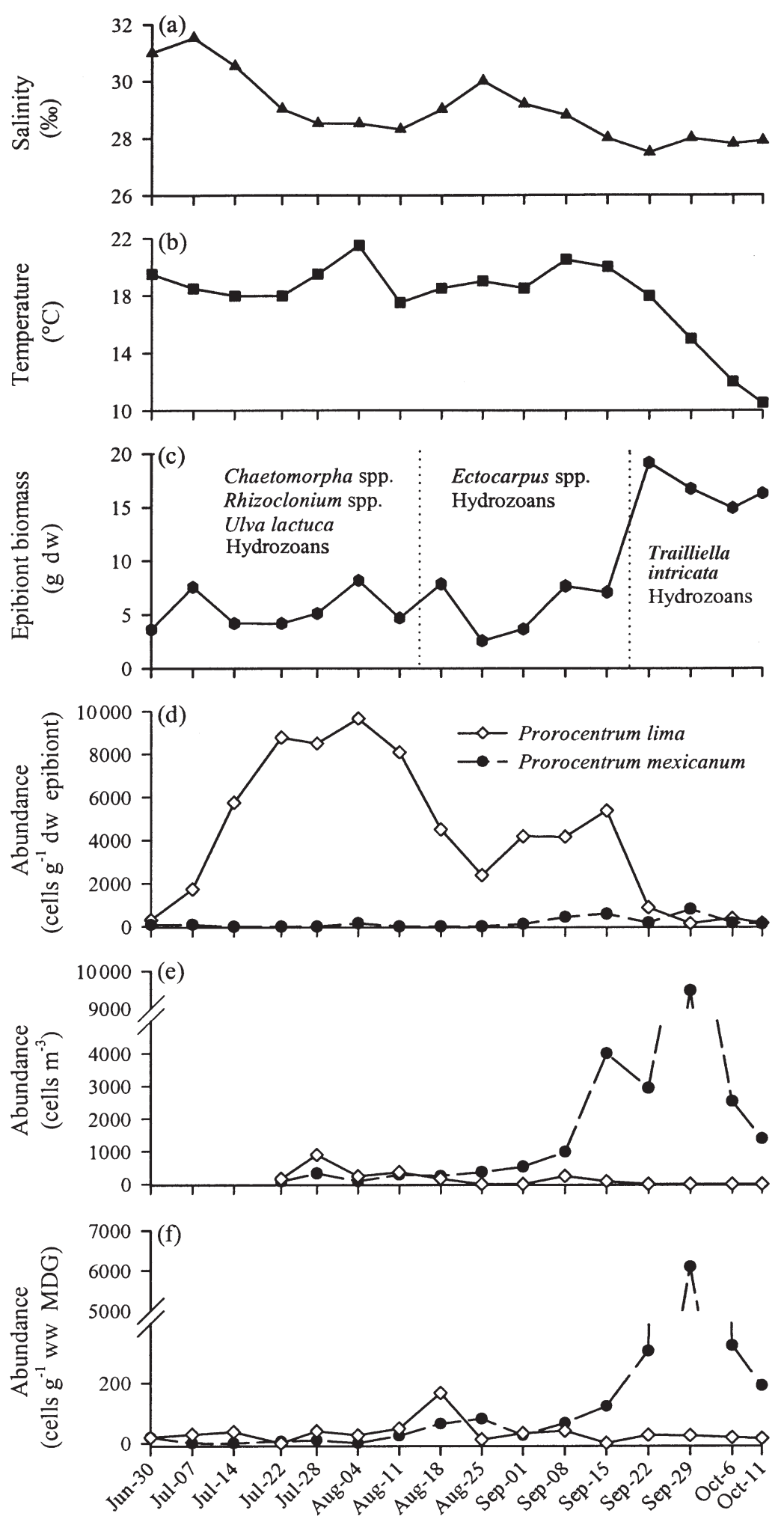

Fig. 2. Temporal variations in (a) salinity, (b) water temperature, (c) epibiont biomass and major genus or species of macroalgae present, the abundance of Prorocentrum lima and P. mexicanum (d) on the epibionts, (e) in the water column, and (f) in mussel digestive glands (MDG) at Havre-aux-Maisons

(HAM) during 1999. dw: dry weight; ww: wet weight pling period (Fig. 2d). In the water column, $P$. lima abundances were low $(<900$ cells $\mathrm{m}^{-3}$ ) and often undetectable (Fig. 2e). P. lima was also found in low abundances in the digestive glands of the mussels, remaining below 170 cells $\mathrm{g}^{-1}$ wet digestive gland wt between June 30 and October 11 (Fig. 2f).

\section{Prorocentrum mexicanum distribution}

Prorocentrum mexicanum was also present in our samples. To our knowledge, this is the first time that this potentially toxic species has been formally identified in eastern Canada. An empty theca resembling $P$. mexicanum was observed in a previous sample from this site, but could not be clearly identified (Bérard-Therriault et al. 1999). On the epibionts, $P$. mexicanum abundances were very low, reaching a maximum of 790 cells $\mathrm{g}^{-1}$ dry epibiont wt on September 29 (Fig. 2d). In the water column, $P$. mexicanum abundances were below 1000 cells $\mathrm{m}^{-3}$ from July 22 to September 8, reached 9500 cells $\mathrm{m}^{-3}$ on September 29, and declined to between 1000 and 2500 cells $\mathrm{m}^{-3}$ in early October (Fig. 2e). The abundance of $P$. mexicanum in the digestive glands of mussels followed the same pattern as in the water column, remaining under 100 cells g ${ }^{-1}$ wet digestive gland wt from the end of June to early September, and increasing above 100 cells $\mathrm{g}^{-1}$ wet digestive gland wt by mid-September and reaching a maximum of 6092 cells g ${ }^{-1}$ wet digestive gland wt on September 29 (Fig. 2f).

\section{Grande-Entrée (GE)}

Physico-chemical parameters

Water salinity ranged between 27.0 and $31.2 \%$ between July 1 and October 5 (Fig. 3a). Water temperature ranged between 17 and $21^{\circ} \mathrm{C}$ from July to mid-September and dropped to $13^{\circ} \mathrm{C}$ in October (Fig. 3b). As observed at the HAM site, nitrogen $\left(\mathrm{NO}_{3}+\mathrm{NO}_{2}\right)$ and phosphate $\left(\mathrm{PO}_{4}\right)$ concentrations were low,

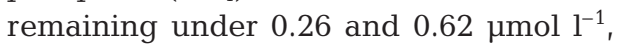
respectively (data not shown). 
Abundance and nature of the epibionts

The distribution of epibionts was similar to that observed at HAM (Fig. 3c). The biomass of epibionts oscillated between 4 and $10 \mathrm{~g}$ dry epibiont wt during the whole sampling period except in late September to early October when it reached $18 \mathrm{~g}$ dry epibiont wt (no epibionts were collected on August 16 and 23). Samples collected between July 1 and August 9 were mainly composed of hydrozoans, Chaetomorpha spp. as well as Polysiphonia spp. From August 30 to September 20, the assemblage was mostly composed of hydrozoans, Rhizoclonium spp. and Bryopsis plumosa. As observed at HAM, the increase in biomass at the end of September resulted from the proliferation of Trailliella intricata.

\section{Prorocentrum lima distribution}

The distributions of both Prorocentrum species at the GE site were remarkably similar to their distribution at the HAM site located ca. $30 \mathrm{~km}$ away. On the epibionts, $P$. lima abundances were low in early July, reached 6000 cells g $^{-1}$ dry epibiont wt on July 19 and 8087 cells $\mathrm{g}^{-1}$ dry epibiont wt on September 6, and decreased abruptly thereafter (Fig. 3d). As at HAM, P. lima abundances were low in the water column, remaining below 300 cells $\mathrm{m}^{-3}$, and were often undetectable (Fig. 3e). $P$. lima was also found in very small quantities in the digestive glands of the mussels, remaining below 80 cells $\mathrm{g}^{-1}$ wet digestive gland wt (Fig. 3f).

\section{Prorocentrum mexicanum distribution}

As observed at HAM, Prorocentrum mexicanum was mainly found in the water column but was also present, albeit in low abundances, on the epibionts, reaching a maximum of 507 cells $\mathrm{g}^{-1}$ dry epibiont wt on September 27 (Fig. 3d). Otherwise, attached $P$. mexi-

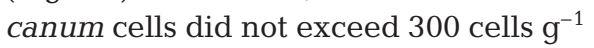
dry epibiont wt, and were often unde-
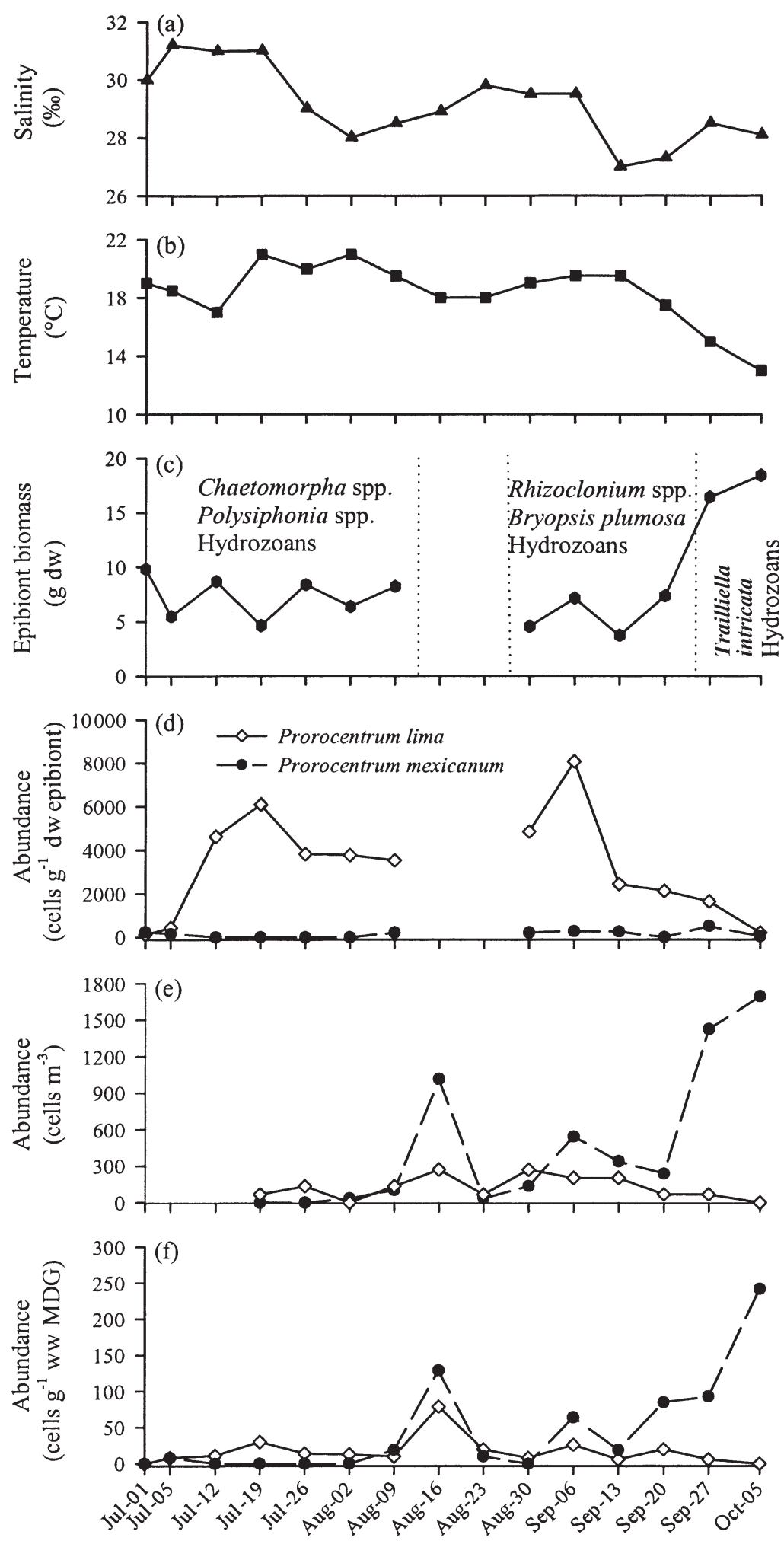

Fig. 3. Temporal variations in (a) salinity, (b) water temperature, (c) epibiont biomass and major genus or species of macroalgae present, the abundance of Prorocentrum lima and $P$. mexicanum (d) on the epibionts, (e) in the water column, and (f) in mussel digestive glands (MDG) at Grande-Entrée (GE) during 1999 
tectable. In the water column, $P$. mexicanum abundances were low throughout the sampling period $\left(<600\right.$ cells $\left.\mathrm{m}^{-3}\right)$ with a small peak on August 16 (1000 cells $\mathrm{m}^{-3}$ ) and a larger one at the end of our sampling season (1700 cells $\mathrm{m}^{-3}$ ) (Fig. 3e). P. mexicanum abundances in mussel digestive glands followed the same pattern as in the water column with maximums in mid-August (129 cells $\mathrm{g}^{-1}$ wet digestive gland wt) and at the end of September to early October (242 cells $\mathrm{g}^{-1}$ wet digestive gland wt) (Fig. 3f).

Toxicological analyses performed on the mussels collected at the 2 sampling sites were negative for OA and DTX.

\section{DISCUSSION}

The results of this study establish the presence of 2 potentially toxic Prorocentrum species in the HAM and GE lagoons of the Magdalen Islands in the Gulf of St. Lawrence, Canada, i.e. P. lima and P. mexicanum. $P$. lima occurs in coastal areas worldwide, in temperate and tropical oceans (Taylor et al. 1995, Faust et al. 1999) and has also been observed at the Magdalen Islands in the past (Bérard-Therriault et al. 1999). $P$. mexicanum is generally described as a tropical or sub-tropical species (Steidinger \& Tangen 1996, Tindall \& Morton 1998). However, the geographic distribution of $P$. mexicanum is not restricted to these warm waters and remains obscure due to taxonomical problems. We regard P. rhathymum Loeblich et al. as a taxonomic synonym of $P$. mexicanum, as proposed by Steidinger (1983). Dodge (1975) regarded P. mexicanum, together with other Prorocentrum species, as conspecific with $P$. maximum (Gourret) Schiller, but he depicted, on his Plate 3 of Fig. F, a specimen with a long apical spine quite different from $P$. mexicanum. A very similar and apparently conspecific specimen with that depicted by Dodge (1975) was published by Halim (1967) (his Plate 7, Fig. 96 and Plate 9, Fig. 134). Since then, there have been many records of $P$. maximum published in the literature, e.g. from the Mediterranean Sea and as far north as North Sutherland (Scotland) (Dodge 1989). The identity of these records remains unclear as no figures are given. However, since 1979, $P$. mexicanum has been reported in the Mediterranean Sea (e.g. Estrada 1979, as P. rhathymum) and seems to be widespread there (M. Elbrächter unpubl. data). P. mexicanum has also been found in the brackish waters of Hamana Lake on the Pacific coast of Japan (Okamoto 1992) and in the temperate waters of the Tasmanian east coast (Pearce et al. 2000). P. mexicanum has also been exceptionally reported on the French Atlantic coast (Nezan \& Piclet 1996, Belin \& Raffin 1998). To our knowledge, in North
America, P. mexicanum has never been recorded north of Florida waters (Bomber et al. 1985) in the Atlantic and north of the Gulf of California (Garate-Lizarraga \& Martinez-Lopez 1997) in the Pacific. Our observations as well as previous observations clearly show that $P$. mexicanum can develop in northern latitudes. Furthermore, the Magdalen Islands lagoons seem to have appropriate physical conditions for $P$. mexicanum, which is known to thrive in protected shallow inshore areas (Carlson \& Tindall 1985, Bomber et al. 1989, Morton \& Faust 1997, Pearce et al. 2000).

The 2 Prorocentrum species were found in the water column, attached to the epibionts and in mussel digestive glands. However, they exhibited a clear difference in their habitat preference, with $P$. lima being more abundantly attached to the epibionts and $P$. mexicanum more abundant in the water column. This is in accordance with Taylor et al. (1995), who noted that both species are epibenthic on seaweeds and that $P$. mexicanum is also planktonic (Fukuyo 1981, Faust 1990, Taylor et al. 1995). Overall, the temporal variations in the abundance of the 2 species were remarkably similar at the 2 sampling sites located ca. $30 \mathrm{~km}$ apart, suggesting that our weekly sampling successfully captured large temporal patterns.

\section{Temporal variations of Prorocentrum lima concentrations in the lagoons}

In both lagoons, Prorocentrum lima was mainly found on the epibionts fouling the mussel socks. Throughout the sampling period, the average abundance of $P$. lima was 4060 cells $^{-1}$ dry epibiont wt at HAM and 2969 cells $g^{-1}$ dry epibiont wt at GE. These abundances are slightly greater than the average 2500 cells $\mathrm{g}^{-1}$ macroalgae measured by Lawrence (1998) in Mahone Bay, Nova Scotia. P. lima abundance was always low $\left(<1000\right.$ cells $\left.\mathrm{m}^{-3}\right)$ in the water column, and we found no relationship (positive or negative) between the abundance of attached and free-living cells. The absence of a relationship is not surprising given the weekly frequency of our sampling. In spite of the low P. lima abundances in the water column, cells were frequently found in mussel digestive glands, suggesting that they were available for ingestion. It is also noteworthy that $P$. lima cells were sometimes found in mussel digestive glands even when they were not detected in the water column, highlighting the inability of standard pelagic monitoring programs to predict toxic outbreaks due to epiphytic species.

Temporal variations of epiphytic microalgae may result from widely different mechanisms. Increases in cell abundance may result from the colonization of the substrate by free-living cells and/or in situ growth of 
already attached cells, while decreases in abundance may result from detachment or mortality of attached cells and/or loss of substrate. The temporal patterns presented in Figs. 2d \& 3d should thus be interpreted with respect to the succession of epibionts. The abundances of attached Prorocentrum lima cells $\mathrm{g}^{-1}$ epibiont at both sites exhibited a strong seasonal pattern. This was characterized by a gradual increase in early July followed by variable but relatively high levels until early September at GE and mid-September at HAM when abundances started to decrease to reach minimum values in early October. Since no sampling was conducted prior to June 30, we may have missed an earlier bloom of $P$. lima. However, the coincidence between the colonization of the epibionts by $P$. lima at both sites is striking and suggests that we may have caught the beginning of the growing season. The appearance of $P$. lima on the epibionts in early summer was not associated with changes in water salinity or temperature, and the weight and taxonomic composition of the epibionts were also stable at both sites during this period. The colonization of the epibionts by $P$. lima in early July was thus not linked to any of these environmental parameters and may have resulted from a circannual internal rhythm. The sharp decrease of attached $P$. lima cells in both lagoons in September appears to be related to vertical mixing caused by strong winds. It is important to point out that the total number of $P$. lima cells (not standardized by $g$ epibiont) also decreased drastically during this period at both sites (data not shown). At HAM in mid-September, the decrease coincided with a shift in the composition of the epibiontic assemblage with the filamentous brown alga Ectocarpus spp. being replaced by the rhodophyte Trailliella intricata. The loss of Ectocarpus spp. (and the associated $P$. lima cells), which was loosely attached to the mussel socks, coincided with the passage of the tropical storm Floyd south of our study area on September 16 to 18 with persistent NNE winds of ca. $10 \mathrm{~m} \mathrm{~s}^{-1}$ (Fig. 4a,b). Since the Magdalen Islands lie on a NE-SW axis, NNE winds favor the development of waves within the lagoons and may affect the HAM sampling station, while the GE station remains protected by the coast (refer to Fig. 1). The physical removal of Ectocarpus spp. seems to have favored the proliferation of $T$. intricata, which remained poorly colonized by $P$. lima for the remainder of the season. During the post-Floyd period, the fouling biomass increased considerably at HAM but $P$. lima abundances remained low, possibly due to the lower water

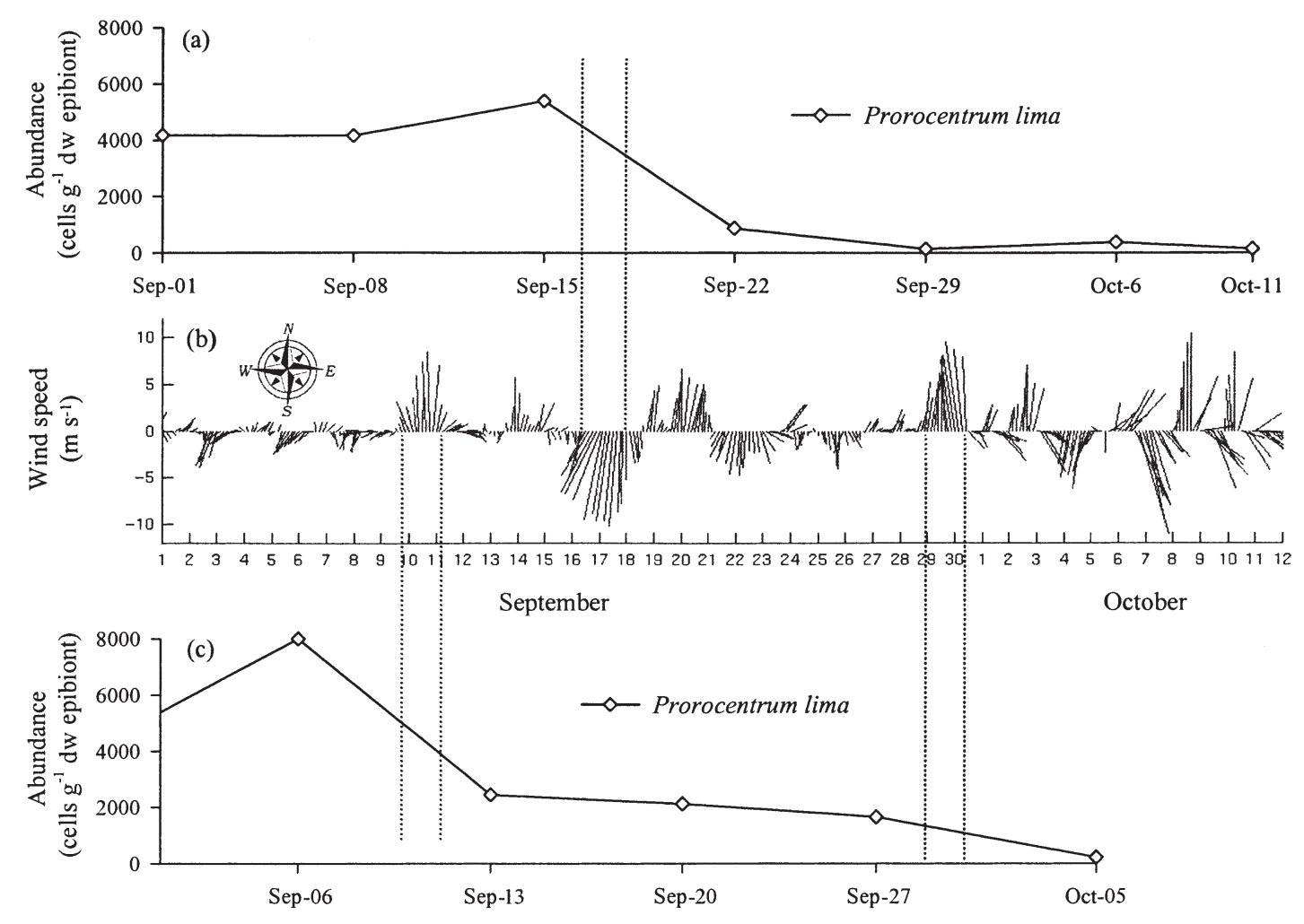

Fig. 4. Temporal variations of Prorocentrum lima on the epibionts in relation to the daily wind speed. Abundance of $P$. lima at (a) Havre-aux-Maisons (HAM), and (c) Grande-Entrée (GE) during September and October 1999. The wind speed and direction are illustrated in (b) 
temperatures. Jackson et al. (1993) showed that the maximal growth rate of $P$. lima strains isolated from Mahone Bay decreased markedly with decreasing temperature, falling from 0.5 divisions $\mathrm{d}^{-1}$ at $20^{\circ} \mathrm{C}$ to 0.1 divisions $\mathrm{d}^{-1}$ at $10^{\circ} \mathrm{C}$. The temperature preferences of $P$. lima strains from the Gulf of St. Lawrence are not known, but water temperatures below $13^{\circ} \mathrm{C}$ in October at HAM may have limited the growth of this species. At GE, P. lima abundance on the epibionts was not affected by the NNE winds of September 16 to 18 , but rather by strong $\mathrm{S}$ winds close to $10 \mathrm{~m} \mathrm{~s}^{-1}$ on September 10 to 11 (Fig. 4b,c). The entrance of the GE lagoon faces SW and is therefore influenced by $\mathrm{S}$ winds (refer to Fig. 1). Strong $S$ winds on September 29 to 30 were also associated with a second decrease in $P$. lima abundance (Fig. 4b,c). Contrary to HAM, these events were not associated with the removal of macroalgae, possibly due to the difference in macroalgae species and the depth of the socks.

Studies by Bomber et al. (1985) and Morton \& Faust (1997) on the epiphytism of dinoflagellates have shown that Prorocentrum lima was widely distributed among macroalgal substrates. P. lima cells occurred on chlorophytes, phaeophytes, rhodophytes and vascular plants although highest densities were observed on chlorophytes, such as Penicillus capitatus and Avrainvillea nigricans (Bomber et al. 1985), as well as on the rhodophyte Acanthophora spicifera (Morton \& Faust 1997). We also found $P$. lima cells in association with epibion-

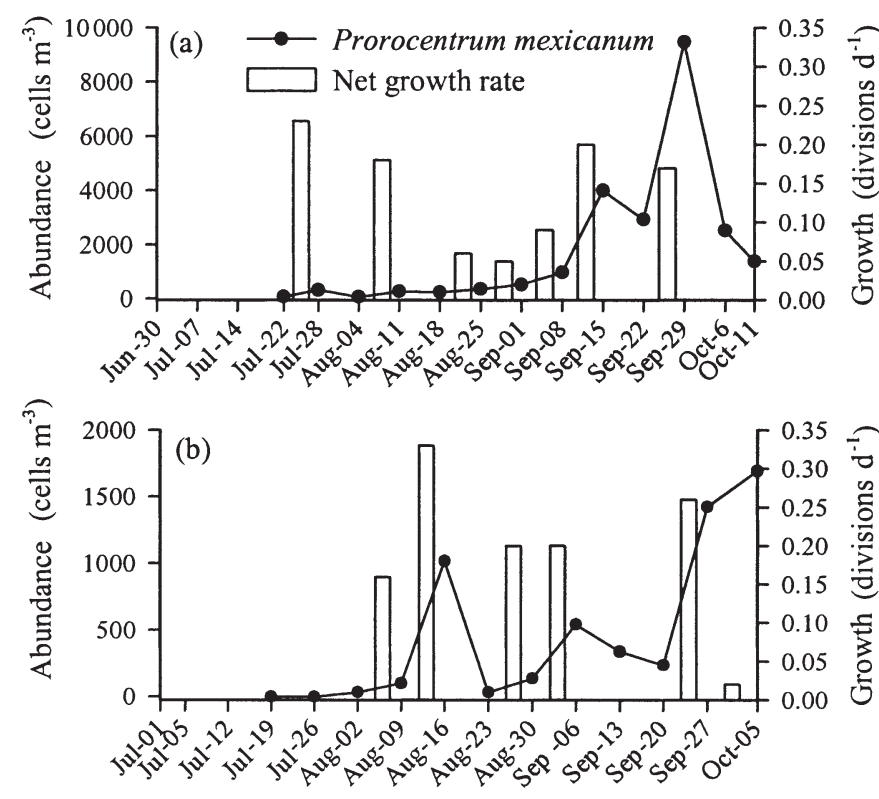

Fig. 5. Summer variations of Prorocentrum mexicanum abundance in the water column and net growth rates of this species (only positive rates are represented) in the lagoons of (a) Havre-aux-Maisons (HAM) and (b) Grande-Entrée (GE) in 1999 tic assemblages dominated by chlorophytes, phaeophytes and rhodophytes. Furthermore, preliminary laboratory experiments showed that $P$. lima strains isolated from the lagoons also attach to members of these 3 algal divisions (Réal Gagnon, Institut Maurice-Lamontagne, Ministère des Pêches et Océans Mont-Joli, Québec, pers. comm.). Like Faust et al. (1999), we also observed that $P$. lima adheres to the walls of culture flasks. The mucus produced by $P$. lima appears to allow cells to adhere to the substratum (Réal Gagnon pers. comm.).

Prorocentrum lima is known to produce OA (Murakami et al. 1982, Marr et al. 1992) and its derivative, methyl-OA (DTX-1) (Lee et al. 1989, Marr et al. 1992). A recent laboratory study has demonstrated that these DSP toxins accumulate in the digestive glands of the mussel Mytilus edulis when toxic P. lima cells are ingested (Pillet et al. 1995). However, in this study, we did not detect OA or DTX-1 in our samples even at the

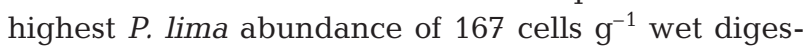
tive gland wt, suggesting that the magnitude of the $P$. lima population in 1999 was insufficient to result in the accumulation of toxins in the mussels. In 1997, in Mahone Bay, the P. lima abundances did not exceed 47 cells $\mathrm{g}^{-1}$ wet digestive gland wt and the toxins were also undetectable (Lawrence 1998).

\section{Temporal variations of Prorocentrum mexicanum in the lagoons}

In the lagoons, Prorocentrum mexicanum was principally found in the water column, but was also attached to the epibionts in very small numbers. At both sites, $P$. mexicanum abundance was generally low in the water column in July and August, but increased substantially in September (Figs. 2e \& 3e). The most significant increase was observed at HAM between September 21 and 29 (9500 cells $\left.\mathrm{m}^{-3}\right)$, a calm period with winds below $5 \mathrm{~m} \mathrm{~s}^{-1}$. At GE, P. mexicanum was found in lower abundance than at HAM, but also increased in late September to early October. In situ growth could explain the temporal changes in $P$. mexicanum abundance observed in the lagoons. To explore whether the weekly changes in $P$. mexicanum abundance could be explained solely by in situ growth (instead of advection), we calculated the net population growth rate from the changes in cell abundance between consecutive sampling days (Fig. 5). Net population growth rates varied between 0.05 and 0.33 divisions $\mathrm{d}^{-1}$. These rates are generally comparable with those of 0.1 and 0.2 divisions $\mathrm{d}^{-1}$ obtained by Morton et al. (1992) with P. mexicanum strains isolated from Knight Key, Florida, grown at salinities comparable to those measured in the lagoons. However, these Florida strains could not grow below $21^{\circ} \mathrm{C}$. The optimum growth temperature for the strains isolated from the Magdalen 

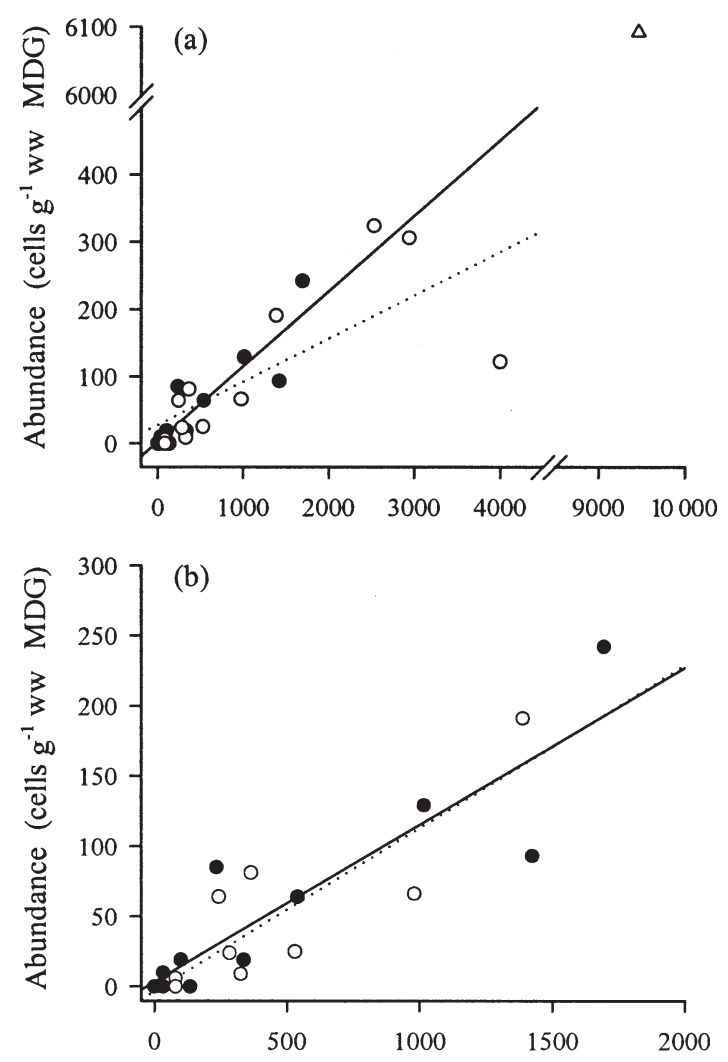

Fig. 6. Relationship between Prorocentrum mexicanum abundance in the water column and in mussel digestive glands $(\mathrm{MDG})$ for Havre-aux-Maisons (HAM) $(\bullet$, dotted line) and Grande-Entrée (GE) (O, solid line) (a) with all data points except the highest value $(\Delta)$ at HAM and (b) within the 0 to 2000 cells $\mathrm{m}^{-3}$ range

Islands lagoons is not known. However, the relatively high net population growth rates measured in late September, when water temperature varied between 15 and $18^{\circ} \mathrm{C}$, suggest that the St. Lawrence strains are acclimated to colder conditions. The temperature in September 1999 was clearly above the seasonal normal, reaching $16.9^{\circ} \mathrm{C}$ compared to the average $12.8^{\circ} \mathrm{C}$. In addition, the daily wind speed of $5 \mathrm{~m} \mathrm{~s}^{-1}$ was below the average $7.5 \mathrm{~m} \mathrm{~s}^{-1}$ recorded by Environment Canada (1993) for the 1961 to 1990 period. Warmer waters and relatively calm conditions may thus have favored the growth and accumulation of $P$. mexicanum in the water column in September during this particular year.

In contrast to Prorocentrum lima, P. mexicanum abundances in the water column and in mussel digestive glands were positively correlated at HAM $\left(\mathrm{r}^{2}=\right.$ 0.545, $y=0.064 x+27.87, \mathrm{n}=12)$ and $\mathrm{GE}\left(\mathrm{r}^{2}=0.809, y=\right.$ $0.11 x+3.27, \mathrm{n}=12$ ) when all data points were included in the regression except for the single highest value (Fig. 6a). Within the 0 to 2000 cells $\mathrm{m}^{-3}$ range, the 2 regression lines are similar: $y=0.12 \mathrm{x}-3.52\left(\mathrm{r}^{2}=0.72\right.$, $\mathrm{n}=9)$ for HAM, and $y=0.11 \mathrm{x}+3.27\left(\mathrm{r}^{2}=0.81, \mathrm{n}=12\right)$ for GE (Fig. 6b). This tight relationship suggests that our weekly sampling was adequate to capture most of the temporal variations in $P$. mexicanum abundance and that the distribution of this species was relatively homogeneous in the lagoons. In practice, this relationship indicates that $P$. mexicanum abundance in mussels (and probably $P$. mexicanum-derived toxins in mussels) could be predicted from cell abundances measured in the water column by regular monitoring programs. The chemical structure of the toxins produced by $P$. mexicanum are undefined, although to date, many toxic effects have been observed. For example, $P$. mexicanum extracts caused death in mice (Tindall et al. 1984, Carlson \& Tindall 1985, Pearce \& Hallegraeff 2001) and also have a toxic effect on guinea pig ileum preps (Bomber \& Aikman 1991). A cytotoxic activity has also been observed with cultures of $P$. mexicanum (S. Morton pers. comm.). Nakajima (1981) and Yasumoto et al. (1987) showed hemolytic activity with extracts of $P$. rhathymum (synonym of $P$. mexicanum). One of the $P$. mexicanum-derived toxins is a water-soluble fast-acting toxin (FAT) which was isolated by Tindall at al. (1989). FAT include spirolides, pinnatoxins and gymnodimine; however, their significance for human health has not yet been determined (Anderson et al. 2001). The presence of P. mexicanum in our samples was unexpected, consequently, the toxins produced by this species were not targeted in the toxicity measurements during our study. As far as we know, $P$. mexicanum does not produce OA or DTX, but diarrhetic effects may also be caused by other toxins like azaspiracids (James et al. 2000). Thus, the possibility that $P$. mexicanum was implicated in the 1998 poisoning incident remains unclear but cannot be ruled out.

\section{CONCLUSIONS}

This research has not allowed us to draw conclusions about the source of DTX found in the farmed mussels of the Magdalen Islands in 1998. However, Prorocentrum lima and $P$. mexicanum were found living in very close proximity to the mussels and were part of their natural diet. Although no toxins were detected in shellfish tissue, this does not indicate that these species are harmless. Further studies are needed to determine the toxicity of these St. Lawrence strains. The unexpected discovery of $P$. mexicanum has introduced a new element into the shellfish poisoning problem at the Magdalen Islands and implies a wider distribution than previously believed for this species in North America. Finally, our results stress the importance of implementing monitoring programs allowing the detection of non-pelagic HABs. 
Acknowledgements. We wish to thank M. Fournier and M. Cyr for access to their mussel farming sites, the staff of the mariculture research station at the Magdalen Islands for access to their laboratories, the Canadian Food Inspection Agency for the toxicological analyses, and L. Bérard-Therriault and S. Lessard for their help in the identification of phytoplankton. This study was mainly supported by funds from the Domaine d'intervention Santé humaine du Plan St-Laurent Vision 2000 and partly supported by grant 03FO161 from the Bundesministerium für Bildung und Forschung (Project TEPS) to M.E.

\section{LITERATURE CITED}

Anderson DM, Andersen P, Bricelj VM, Cullen JJ, Rensel JE (2001) Monitoring and management strategies for harmful algal blooms in coastal waters. APEC 201-MR-01.1, Asia Pacific Economic Program (APEC), Singapore, and Intergovernmental Oceanographic Commission Technical Series No. 59, Paris

Bates SS (1997) Toxic phytoplankton on the Canadian east coast: implications for aquaculture. Bull Aquac Assoc Can 97(3):9-18

Belin C, Raffin B (1998) Les espèces phytoplanctoniques toxiques et nuisibles sur le littoral français de 1984 à 1995, résultats du REPHY (réseau de surveillance du phytoplancton et des phycotoxines) tome 1. IFREMER, Plouzane

Bérard-Therriault L, Poulin M, Bossé L (1999) Guide d'identification du phytoplancton marin de l'estuaire et du golfe $\mathrm{du}$ Saint-Laurent incluant également certains protozoaires. Publ Spec Can Sci Halieutiques Aquat 128: $141-240$

Bomber JW, Aikman KE (1991) The ciguatera dinoflagellates. Biol Oceanogr 6:291-311

Bomber JW, Norris DR, Mitchell LE (1985) Benthic dinoflagellates associated with ciguatera from the Florida Keys. II. Temporal, spatial and substrate heterogeneity of Prorocentrum lima. In: Anderson DM, White AW, Badens DG (eds) Toxic dinoflagellates. Elsevier Scientific Publishing, New York, p 45-50

Bomber JW, Rubio MG, Norris DR (1989) Epiphytism of dinoflagellates associated with the disease ciguatera: substrate specificity and nutrition. Phycologia 28:360-368

Carlson RD, Tindall DR (1985) Distribution and periodicity of toxic dinoflagellates in the Virgin Islands. In: Anderson DM, White AW, Badens DG (eds) Toxic dinoflagellates. Elsevier Scientific Publishers, New York, p 171-176

Cembella AD, Berdalet E, Gilgan MW, Lakshminarayana JSS and 7 others (1992) Diarrhetic shellfish poisoning in Canada. In: Therriault JC, Levasseur M (eds) Proc 3rd Can Workshop Harmful Mar Algae. Can Tech Rep Fish Aquat Sci 1893:57-65

Dodge JD (1975) The Prorocentrales (Dinophyceae) II. Revision of the taxonomy within the genus Prorocentrum. Bot J Linn Soc 71:103-125

Dodge JD (1989) Records of marine dinoflagellates from North Sutherland (Scotland). Br Phycol J 24:385-389

Environment Canada (1993) Canadian climate normals 1961-1990. Atmospheric Environment Service, Environment Canada, Ottawa

Estrada M (1979) Observations sobre la heterogeniidad del fitoplancton en una zona costera del mar Catalán. Invest Pesq 43:637-666

Faust MA (1990) Morphologic details of six benthic species of Prorocentrum (Phyrrophyta) from a mangrove island,
Twin Cays, Belize, including two new species. J Phycol 26: $548-558$

Faust MA, Larsen J, Moestrup O (1999) ICES identification leaflets for plankton. In: Lindley JA (ed) Potentially toxic phytoplankton. 3. Genus Prorocentrum (Dinophyceae), no. 184. ICES, Copenhagen, p 24

Fukuyo Y (1981) Taxonomical study on benthic dinoflagellates collected in coral reefs. Bull Jpn Soc Sci Fish 47: 967-978

Garate-Lizarraga I, Martinez-Lopez A (1997) Primer registro de una marea roja de Prorocentrum mexicanum (Prorocentraceae) en el Golfo de California. Rev Biol Trop 45: 1263

Halim Y (1967) Dinoflagellates of the South-East Caribbean Sea (East Venezuela). Int Rev Ges Hydrobiol 52:701-755

Jackson AE, Marr JC, McLachlan JL (1993) The production of diarrhetic shellfish toxins by an isolate of Prorocentrum lima from Nova Scotia, Canada. In: Smayda TJ, Shimizu Y (eds) Toxic phytoplankton blooms in the sea. Elsevier Scientific Publishers, Amsterdam, p 513-518

James KJ, Furey A, Satake M, Yasumoto T (2000) Azaspiracid poisoning (AZP): a new shellfish toxic syndrome in Europe. In: Hallegraeff GM, Blackburn SI, Bolch CJ, Lewis RJ (eds) Harmful algal blooms, Intergovernmental Oceanographic Commission of UNESCO 2001. UNESCO, Paris, p 250-253

Lawrence JE (1998) Population dynamics and toxicity of the epiphytic dinoflagellate Prorocentrum lima in a shallow coastal embayment: implications for shellfish aquaculture. PhD thesis, Department of Oceanography, Dalhousie University, Halifax, NS

Lawrence JE, Bauder AG, Quilliam MA, Cembella AD (1998) Prorocentrum lima: a putative link to diarrhetic shellfish poisoning in Nova Scotia, Canada. In: Reguera B, Blanco J, Fernandez ML, Wyatt T (eds) Harmful algae. Xunta de Galicia Intergovernmental Commission of UNESCO, Paris, p 78-79

Lawrence JE, Grant J, Quilliam MA, Bauder AG, Cembella AD (2000) Colonization and growth of the toxic dinoflagellate Prorocentrum lima and associated fouling macroalgae on mussels in suspended culture. Mar Ecol Prog Ser 201: $147-154$

Lee JS, Igarashi T, Fraga S, Dahl E, Hovgaard P, Yasumoto T (1989) Determination of diarrhetic shellfish toxins in various dinoflagellate species. J Appl Phycol 1:147-152

Marr JC, Jackson AE, McLachlan JL (1992) Occurrence of Prorocentrum lima, a DSP toxin-producing species from the Atlantic coast of Canada. J Appl Phycol 4:17-24

Morton SL, Faust MA (1997) Survey of toxic epiphytic dinoflagellates from the Belizean barrier reef ecosystem. Bull Mar Sci 61:899-906

Morton SL, Norris DR, Bomber JW (1992) Effect of temperature, salinity and light intensity on the growth and seasonality of toxic dinoflagellates associated with ciguatera. J Exp Mar Biol Ecol 157:79-90

Morton SL, Leighfield TA, Haynes BL, Petipain DL and 6 others (1999) Evidence of diarrhetic shellfish poisoning along the coast of Maine. J Shellfish Res 18:681-686

Murakami Y, Oshima Y, Yasumoto T (1982) Identification of okadaic acid as a toxic component of a marine dinoflagellate Prorocentrum lima. Bull Jpn Soc Sci Fish 48:69-72

Nakajima I, Oshima Y, Yasumoto T (1981) Toxicity of benthic dinoflagellates in Okinawa. Bull Jpn Soc Sci Fish 47: 1029-1033

Nezan E, Piclet G (1996) Guide pratique à l'usage des analystes du phytoplancton: 66 fiches. IFREMER, Plouzane Okamoto K (1992) Dinoflagellates found in Hamana Lake. 
I. Genus Prorocentrum. Bull Plankton Soc Jpn 38:121-133

Parsons TR, Maita Y, Lalli CM (1984) A manual of chemical and biological methods for seawater analysis. Pergamon Press, Oxford, p 3-28

Pearce I, Hallegraeff GM (2001) Toxic epiphytic dinoflagellates from Tasmania. 16th Aust Soc Phycol Aquat Bot (ASPAB) Conf. Heron Island, North Queensland, Australia, Abstract Booklet, p 37

Pearce I, Marshall JA, Hallegraeff GM (2000) Toxic epiphytic dinoflagellates from East Coast Tasmania, Australia. In: Hallegraeff GM, Blackburn SI, Bolch CJ, Lewis RJ (eds) Harmful algal blooms, Intergovernmental Oceanographic Commission of UNESCO 2001. UNESCO, Paris, p 54-57

Pillet S, Pereira A, Braekman JC, Houvenaghel G (1995) Patterns in long-term accumulation of okadaic acid and DTX1 in blue mussels Mytilus edulis, experimentally fed with the DSP-containing alga Prorocentrum lima. In: Lassus P, Arzul G, Erard-Le Denn E, Gentien P, Marcaillou-Le Baut C (eds) Harmful marine algal blooms. Lavoisier Science Publishers, Paris, p 487-492

Quilliam MA, Gilgan MW, Pleasance S, Defreitas ASW and 6 others (1993) Confirmation of an incident of diarrhetic shellfish poisoning in Eastern Canada. In: Smayda TJ, Shimizu Y (eds) Toxic phytoplankton blooms in the sea. Elsevier Scientific Publishers, Amsterdam, p 547-552

Sournia A, Belin C, Berland B, Erard-Le Denn E and 5 others (1991) Le phytoplancton nuisible des côtes de France, de la biologie à la prévention. IFREMER, Plouzane, p 47-49

Steidinger KA (1983) A re-evaluation of toxic dinoflagellate biology and ecology. Prog Phycol Res 2:147-188

Editorial responsibility: Paul Harrison,

Kowloon, Hong Kong
Steidinger KA, Tangen K (1996) Dinoflagellates. In: Tomas CR (ed) Identifying marine diatoms and dinoflagellates. Academic Press, San Diego, p 387-584

Taylor FJR, Fukuyo Y, Larsen J (1995) Taxonomy of harmful dinoflagellates. In: Hallegraeff GM, Anderson DM, Cembella AD (eds) Manual on harmful marine microalgae. IOC manuals and guides, no. 33. UNESCO, Paris, p 283-317

Tindall DR, Morton SL (1998) Community dynamics and physiology of epiphytic/benthic dinoflagellates associated with ciguatera. In: Anderson DM, Cembella AD, Hallegraeff GM (eds) Physiological ecology of harmful algal blooms. Springer-Verlag, Berlin, p 293-313

Tindall DR, Dickey RW, Carlson RD, Morey-Gaines G (1984) Ciguatoxigenic dinoflagellates from the Caribbean Sea. In: Ragelis EP (ed) Seafood toxins. ACS symposium series, no. 262. American Chemical Society, Washington, DC, p 225-240

Tindall DR, Miller DM, Bomber JW (1989) Culture and toxicity of dinoflagellates from ciguatera endemic regions of the world. Toxicon 27:83 (Abstract)

Van de Riet JM, Burns BG, Gilgan MW (1995) A routine HPLC-fluorescence method for the determination of the diarrhetic shellfish toxins okadaic acid and DTX-1 in shellfish. Can Tech Rep Fish Aquat Sci 1985:vii + 26 p

Yasumoto T, Inoue A, Bagnis R, Garcon M (1979) Ecological survey on a dinoflagellate possibly responsible for the induction of ciguatera. Bull Jpn Soc Sci Fish 45:395-399

Yasumoto T, Seino N, Murakami Y, Murata M (1987) Toxins produced by benthic dinoflagellates. Biol Bull 172: $128-131$

Submitted: March 13, 2002; Accepted: August 30, 2002 Proofs received from author(s): January 13, 2003 